\title{
Increased Triple Jump Learning Outcomes Through Used TiresAnd Cardboard Tools In Class Xii Ips 5 Students Of SMA Negeri 3 Bone
}

\author{
Muliadi \\ \{Muliadi6452@unm.ac.id\}
}

PGSD FIP Universitas Negeri Makassar, Indonesia

\begin{abstract}
This research is a class action research aimed at describing the use of used tires and cardboard tools to improve learning outcomes of triple jump in class XII IPS 5 students of SMA Negeri 3 Bone, Bone Regency, Academic Year 2017/2018. The subject of this research was class XII IPS 5 of SMA Negeri 3 Bone of Bone Regency with a total of 32 students. The action is carried out in two cycles, and each cycle consists of several stages, namely the initial reflection stage, action planning, action implementation, observation, and reflection. The collected data is then presented qualitatively in a descriptive quantitative manner. The results of this study concluded that; (1) Quantitatively, the triple jump learning outcomes through the use of tools used tires and cardboard students of class XII IPS 5 of SMA Negeri 3 Bone in Bone Regency, before the implementation of the average class action 73.03 , out of 32 students there were $46.87 \%$ of which complete learning outcomes, $53.13 \%$ are incomplete categorized as less, because they have not yet reached the KKM that has been set 75. After the implementation of the first cycle of action is categorized as moderate with an average value of $76.46,71.87 \%$ of incomplete completeness $28,13 \%$. Cycle II was categorized as good with an average value of 79.5, $96.87 \%$ of completion, only $3.13 \%$ of unfinished. From the results of the above analysis, it can be concluded that using tires and cardboard tools can improve the process and learning outcomes of triple jump in class XII IPS 5 SMA Negeri 3 Bone, Bone Regency both quantitatively and qualitatively.
\end{abstract}

Keywords: learning outcomes, triple jump, physical education learning

\section{Introduction}

Sports and health physical education is basically a comprehensive part of the education system, which aims to develop aspects of health, physical fitness, critical thinking skills, emotional stability, social skills, reasoning, and moral action through physical activities, sports and health. But in its ongoing implementation is a process of human development that lasts a lifetime. The role of physical education, sports and health is very important, which provides opportunities for students to be directly involved in various learning experiences through systematic physical, play, and sports activities. The debriefing of the learning experience is directed at fostering, as well as forming a healthy lifestyle, and active throughout life.

Athletics is one of the excellent activities in the process of teaching and learning physical education in high school. In every physical education activity the teacher always prioritizes athletics as; opening, core, or closing teaching and learning activities. This fact is evidence that athletics have more value, especially in the formation of physical quality of students to develop more primed and dynamic. Given the importance of athletics for the education of high school students, it is necessary for the teacher to work on a new model of development so that 
it can be developed in a way that is more interesting and pleasing to students. Teachers need to try as optimal as possible in designing the forms of their activities. Without a maximum effort, it is impossible for athletic learning to run effectively and even more will refer to negative attitudes and boredom of students towards athletic activities that seem monotonous [1].

States that in athletic learning in high school there is no need for the latest equipment, but even with simple equipment learning can live and achieve goals effectively through the use of learning aids. With the use of teaching aids (media), the teacher must be able to utilize various facilities and infrastructure in the school environment because the tools used are sufficient tools that are modified by the teacher and students together [2].

One of the subject matter related to the Athletics numbers, this research will study and examine triple jump. This is because, students in general have not mastered the triple jump technique, even students are less happy with this learning compared to game material. This was experienced in class XII IPS 5 of SMA Negeri 3 Bone in Bone Regency.

Not yet optimal ways or models of athletic learning in schools will have an impact on the low student learning outcomes of athletic material, especially the triple jump numbers. Because teaching triple jumping in schools with a large number of students will result in less effective learning. Besides many factors that influence the low student learning outcomes, among others, the lack of effective physical education teachers in schools in making and developing learning media.

There is a lack of learning models, so that in the process of learning physical education, especially triple jumping material at school is carried out in monotonous situations. Physical education that has been carried out at SMA Negeri 3 Watampone, Bone Regency, there are still obstacles encountered, including students who are not happy with triple jumping lessons, and students are not really taking the lessons. This was proven from 32 students, only 12 students who were said to have reached the target, meaning that only about $34.29 \%$ of the total number of students declared complete in learning with a KKM 75 complete limit.

Of the various causes of the problem that actually arises is the quality of teaching and learning processes or learning patterns that are less good, resulting in mastery and skills in class XII IPS 5 students of SMA Negeri 3 Bone, Bone Regency on athletic material triple jumping numbers have difficulty.

Based on the background stated above, the authors intend to hold a Classroom Action Research in Class XIII PS5 students of SMA Negeri 3 Watampone Bone Regency Academic Year 2017/2018, with the title Improving Triple Jump Learning Outcomes Through Used Tires aids to Class XII IPS 5 Students of SMA Negeri 3 Bone, Bone Regency.

\section{Methods}

The type of research used is Classroom Action Research (CAR) or Classroom Action Research. Classroom action research is research carried out by teachers in their own class through self-reflection, with the aim of improving performance as a teacher, so that student learning outcomes are improved [3]. Meanwhile that class action research is a study conducted by teachers to improve the quality of learning in their classrooms, the mission of this action is to empower teachers and students at the same time [4].

Based on the above opinion it can be concluded that classroom action research is a learning process carried out by the teacher, which involves collaborators and students who are studied to improve the quality of learning so that student learning outcomes improve.

The subjects of this study were students of class XII IPS 5 of SMA Negeri 3 Bone of Bone Regency in the odd semester of the academic year 2017/2018 with 32 students. The research 
was carried out in July - November 2017 which began in the second week of July to the third week of November 2017.

The research was located in Bone 3 High School, Bone Regency (Ex SMA Negeri 2 Watampone Bone Regency) which is located at Jalan Jenderal Gatot Soebroto No. 1, Bone Regency, South Sulawesi Province.

In outline the procedure of this study includes four stages, namely Planning, Action, Observing, and Reflecting. Each of these stages can be described as follows: [3]

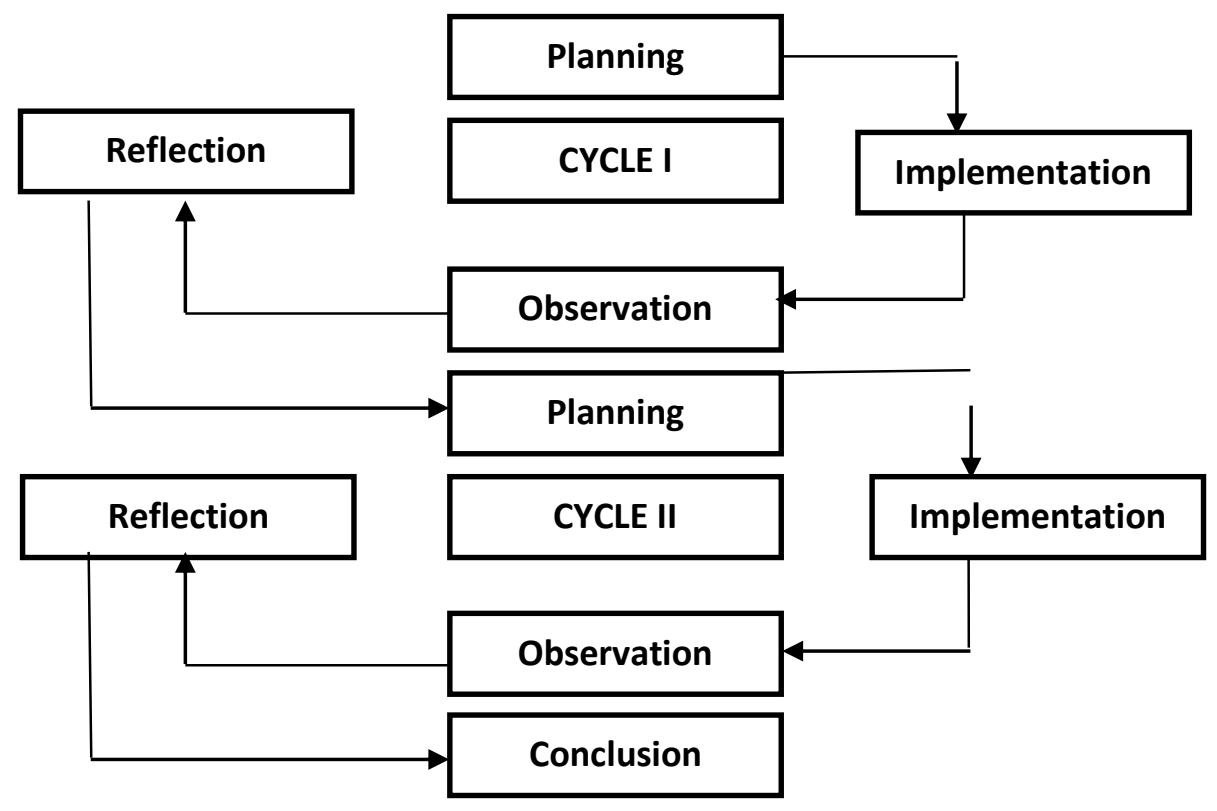

Chart 2.1 Class Action Research Flow [3]

Based on the chart above the class action research process includes 4 stages of research, namely:

1. Plan, which is what action plan will take to improve, enhance or change behavior and attitudes as a solution. At the planning stage, planning is done based on the identification of problems at the initial observation before the research is carried out. This action plan includes all the steps of action in detail at this stage all the needs of the implementation of the class action researchers are prepared starting from teaching materials, lesson plans, learning methods and strategies, approaches to be used, research subjects as well as techniques and observation instruments adjusted to the plan.

2. Actions, namely what is done by the teacher or researcher as an effort to repair, increase or change desired. The action is adjusted to the plan that was made earlier. Action implementation is a process of classroom learning activities as a realization of the theory and approach to teaching and learning that has been prepared and refers to the applicable curriculum, and the results obtained are expected to increase the collaboration of researchers with research subjects so that they can provide reflection and evaluation of what is happening in the classroom.

3. Observation, namely observing the results or the impact of actions carried out or imposed on students. The observation phase is a direct observation of the action taken by PTK. 
The main purpose of observation is to find out whether there is a change that occurs with the implementation of the ongoing action.

4. Reflection, the researcher examines, sees and considers the results or effects of actions from various criteria. Based on the results of this reflection, the researcher together with the teacher can make revisions to the improvement of the initial plan. Through reflection, the teacher will be able to determine what has been achieved, what has not been achieved, and what needs to be improved again in subsequent learning. Therefore the results of actions need to be reviewed, seen and pondered, both in terms of the learning process between the teacher and students, the learning approach, teaching aids and evaluation.

Data collection methods in this study, namely:

1. Data Sources. The source of the data in this study was the teacher and students of class XII IPS 5 in SMA Negeri 3 Bone, Bone Regency.

2. Types of data in the form of quantitative and qualitative data obtained through (1) observation, (2) teacher notes, and (3) learning outcomes.

Data analysis in this study was carried out in three stages. Suggested three stages that must be done in analyzing qualitative research data, namely (a) data reduction; (b) data exposure (data display); and (c) conclusion drawing and verification (conclusion drawing verifying) [5].

\section{a. Data Reduction}

Reducing data that is summarizing, selecting the main points focus on the things that are important and will provide a clear picture, and make it easier for researchers to conduct further data collection until the preparation of the report.

\section{b. Data Display}

Presentation of data is done by compiling narratively, a collection of information that has been obtained from the results of the reduction, so that it can provide the possibility of drawing conclusions and drawing actions. The information in question is a description of the process of learning activities, improvement of student understanding, difficulties faced by students and the results obtained as a result of giving actions. The data that has been presented is then made of interpretation and evaluation to make further planning. The results of interpretation and evaluation can be in the form of an explanation of, 1) the difference between design and action, 2) the need for action changes, 3) alternative actions that are considered appropriate, 4) researchers' perceptions of the actions taken, and 5) the constraints faced and the causes of the constraints it appears.

c. Conclusion Drawing (drawing conclusions and verification)

Drawing conclusions is to provide conclusions on the results of interpretation and evaluation. Conclusions are drawn based on data that has been presented and is the final disclosure of the results of the action.

The conclusion of this research is the descriptive statistical analysis. The results of the analysis obtained in the form of quantitative data were then interpreted through categorization techniques which became the quality of learning outcomes. The conclusion taking refers to the process of analyzing data, categorical techniques and interpreting categories.

The level of success of the action includes changes in students following the backward roll gymnastics learning, students look active, enthusiastic, proud, happy, understand in 
following the learning and is characterized by increased values and skills, mastering the attitude of the back roll motion. Indicator of the success of this action is said to be successful and stop if the level of success of students in this study is measured using a standard value of the limits of the achievement of $85 \%$ of all students in the class, on mastery of skills and triple jumping techniques. And if the individual student scores reach the Minimum completeness Criteria in a triple jump, the lowest grade limit is 75 .

The success of students in triple jumping that describe student learning outcomes is used scale with the following categories:

Table 3.1 Success of triple jumping

a. Very High (ST) if students get a score of 95-100

b. High (T) if students get grades 85-94

c. Medium (S) if students get a score of 75-84

d. Low (R) if students get grades 65-74

e. Very Low (SR) if students get grades 0-64 Source: [6]

\section{DISCUSSION}

Based on the results of the preliminary data description, that the learning outcomes of Class XII IPS 5 infectious triple jumping at SMA Negeri 3 Bone, Bone Regency Academic Year 2017/2018, before the act was given out of 32 students there were 15 students or $46.37 \%$ complete, and 17 students or $53.13 \%$ of students who have not yet completed their learning outcomes in the PJOK Athletics triple jump material in accordance with the KKM set by the school. Then the class average is 73.03 .

\section{a. Cycle I}

\section{i. Cycle Action Plan I}

Researchers and collaborators devise the following Cycle I action implementation plan:

1) The researcher together with collaborators designed a triple jump learning scenario using learning by modifying aids, used tires and cardboard, to improve students' motivation and ability to triple jump so that learning outcomes can be improved.

2) Researchers and collaborators draw up a Learning Implementation Plan (RPP) for triple jump learning using used tires and cardboard tools.

3) Researchers and collaborators prepare equipment that will be used in the implementation of the triple jump learning process planned in the CSP.

4) Researchers and collaborators compile learning observation sheets which are for students and teachers. While the observation sheet was assessed based on the observation guidelines conducted by the researcher by observing the activeness and attitudes of students during the learning activities taking place.

\section{ii. Implementation of Action Cycle I}

The implementation of class action in the learning process in cycle 1 (one) lasted for two meetings, the first meeting was held on Thursday 27 July 2017, the second meeting was held on Thursday 3 August 2017, During 3 lesson hours (135 minutes) with the sequence of activities as follows : 
1) The teacher starts the learning by greeting, praying, presenting and informing the learning up to four triple jump meetings.

2) The teacher addresses the learning objectives associated with past lessons and everyday life

3) The teacher explains the facilities (tools) used

4) The teacher gives a demonstration of the prefix training to tiptoe, step and jump or land using used tires and cardboard.

5) Teachers Group students heterogeneously (those with high intelligence, moderate and low) of 5 (five) groups.

6) Warm up with a variety of strengthening, stretching, flexing movements that lead to core learning.

After warming up the teacher tells the children to do the tiering exercises as a group, students do tiering exercises, stepping, and jumping using the tools of used tires and cardboard alternately brought by the teacher's guidance with collaborators. After a number of tiers of exercise, steps, jumping with assistive devices and cardboard boxes to attract motivation so students are happy, students are assigned exercises to do the actual triple jump on the long jump / jump field (sandbox) field and remain the teacher and collaborator direct it / guide it. Before being given an evaluation students are given the opportunity to give feedback (reflection) about things that are not clear in the implementation of the triple jump. At the end of learning the students are evaluated the triple jump technique skills according to the correct jump rules namely; prefix or square, leaning tiptoe, stepping, and jumping (landing) in a sandbox. The evaluation is done individually and the learning ends with calming / restoring the child's normal condition.

\section{ii. Observation}

In the first cycle the collegiator (colleague) observes, evaluates, and documents the things that occur in the learning process both to the teacher as a researcher and to students. Observations and assessments made by the colabolator with the following results:

1) Teacher Observation Results

Based on observations of the learning process during the process can be obtained observations of the teacher in delivering material at the first meeting with the second meeting, the picture of learning is as follows:

a) In the preliminary learning begins with greetings, praying, attendance and explanation of the material about triple jump, then the teacher gives warm up and all students pay attention and do with high spirits.

b) Core activities

Of all the children actively doing what was assigned by the teacher with enthusiasm, it seemed that the students were motivated because usually the triple jump they did directly in the sandbox, while the triple jump done were using interesting tools and varied movements because used tires and boxes were placed in such a way that students can pass by tiptoeing, stepping and jumping (landing) technical movements. The basic jumping technique moves made by students stay in groups, the aim being that students can work together to help one another. This makes students very happy and can compete students in their groups.

c) Closing activities

In the closing activity the teacher does reflection with the aim that the weaknesses or mistakes made by students are given an explanation so that students do not experience difficulties. 
2) Observation Results of Student Learning

After completing the action in the first cycle the researcher and the collaborator discuss the observations that have been made at the first and second meetings. The learning process of the first cycle from the observations of collaborators is that students have been active, creative, enthusiastic and very happy to take lessons, this can be seen by the number of students who ask the teacher / researcher, as well as their own friends if there is something unclear or lacking understood. The other thing also seems to be that students have started to dare to triple jump with high confidence, although there are still some students who need help from the teacher / researcher and also to their friends, the responsibility and cooperation of students appears between groups is also quite good because there is mutation to always want try / do triple jump movements. Apart from the collaborators' observations, the test results after the first and second meetings in Cycle I proved that the learning outcomes had improved the quality of the process and learning outcomes when compared to the learning outcomes before the action research was carried out, from 32 students averaging 73.03 grades. Students who completed 15 students or $46.87 \%$ and 17 students who were incomplete or $53.13 \%$. When compared to the learning outcomes in Cycle I after the cycle test, there was a pretty good improvement, from 32 students on average to 76.46, 23 students who completed or $71.87 \%, 9$ students who unfinished or $28,13 \%$.

\section{iii. Reflection}

After completing the action the researcher and the collaborator discuss the results of the observation to not continue. With this action research can increase the enthusiasm of students in learning, especially in the material triple jumping.

Based on the results of the first cycle test, the learning outcomes of triple jumping, the researchers together with the collaborator (peers) reflected on the weaknesses and shortcomings made by students in Cycle I, then comparing the results of the first and second learning research obtained 9 students' incomplete data or $28.13 \%$, while those who have completed 23 students or $71.87 \%$. In accordance with the research indicators established by researchers that the KKM PJOK is 75 and this study is successful if it reaches a minimum of $75 \%$ classically, therefore in this first cycle only reached $71.87 \%$ which completes its learning outcomes in triple jump. Thus the researcher and the collaborator collaborate and the results agreed upon by the class action research are continued to continue to the second cycle in order to obtain maximum results according to the established research indicators.

\section{b. Cycle II}

\section{i. Planning}

At this stage, researchers and collaborators based on the discussion have recorded and identified and analyzed what will be done in the action research in cycle II, the result of reflection from the first cycle (I). Learning scenarios are made in the form of lesson plans (RPP), preparing learning aids, preparing observation sheets for teachers and students, making assessment sheets.

\section{ii. Action Implementation}

The implementation of class action in the second cycle learning process took place twice on Thursday, August 10, 2017 and Thursday, August 24, 2017 for 3 hours (135 minutes). In the second cycle the fourth meeting was not held on August 17 because the Indonesian Independence Day was proclaimed to be held on Thursday, August 24, 2017. As for the 
course of learning the triple jumping was as follows: beginning with prayer, presence, apperception, and conveying the learning objectives to be achieved. Then proceed with a warm up that leads to core learning.

This learning is intended for triple jump material which is packaged in the form of play so that students are interesting and happy. Students in groups do tying exercises by passing 6 tires, then do step exercises by passing 6 boxes as well, then land with both feet flat, this teacher and collaborators continue to supervise and provide guidance to students who experience difficulties. After all groups have done the exercise with the help of used tires and cardboard students are directed to the triple jump field to apply the triple jump technique and to apply simple jump rules. The next activity is to give feedback to students who are not yet skilled in performing the triple jump movement technique properly. And before learning ends students are given a cycle test to determine the ability and skills to do a triple jump.

\section{iii. Observation}

The implementation of this research the researchers together with a collaborator (peers) made observations using observation sheets for the teacher and for students during the learning process. The results of the observation are as follows:

1. Teacher Observation Results

a) The teacher has implemented the triple jump learning according to the lesson plan well.

b) Basically learning triple jumping through the use of tools used tires and cardboard enough to give new enthusiasm to students, this can be seen from the active role of students both individually and in groups during the learning process takes place many students who ask to repeat the rising movement, move, and jump, because they think of playing and are not satisfied with the results that have been obtained.

2. Observation Results of Student Aspects

a) Student activity

The learning process activities are able to encourage activity and creativity, and also delight students to move during the learning activities. Most students can complete the assignments given by the teacher quite well, but they still carry the guidance of collaborators with researchers.

b) Student motivation

The learning atmosphere looks very pleasant, this is evidenced by some students who look very happy and do not seem to be bored doing activities, in contrast to the previous atmosphere or in cycle one action.

c) Assessment of the triple jump technique

The results of the assessment of the development of triple jumping skills by using an assessment sheet conducted by collaborators, obtained the results that of 33 students experienced a good increase, this can be shown the average class in this second cycle that is 79.5 students who get a total score of 31 students or amounted to $96.87 \%$ and students who did not complete as many as 1 student or $3.13 \%$.

\section{iv. Reflection Cycle II}

The results of the reflection of learning activities in the second cycle showed that the triple jump learning outcomes increased from $46.87 \%$ in the initial conditions to $71.87 \%$ in the first cycle and increased to $96.87 \%$ in the second cycle. From the comparison of the increase in percentage, the teacher is able to provide good triple jumping learning material, namely through the use of used tires and cardboard tools as a learning medium. In the process of 
learning triple jumping have an impact on students' enthusiasm in participating in good learning so that students are able to understand and perform triple jumping, stepping and jumping techniques to the maximum and also achieving maximum learning outcomes as well. The use of learning tools used for tires and cardboards that are easy to obtain and inexpensive can actually provide problem solving for students as an alternative in the learning process in order to increase the active role of students in participating in jumping learning so that students can understand and perform basic jumping movement techniques well and they are increasingly confident, brave, responsible in doing the tasks of the teacher. From the percentage above, the learning outcomes of triple jumping in the second cycle have met the expected target, or have met the indicators of success.

Some things that can be obtained from the results of the action phase research are the results of the actions in the first cycle, the observations of the learning process that relate to the attitude of students' activities while participating in learning. In the learning process students look active in following all the assignments or exercises given by the teacher. But in learning in this first cycle, there were still obstacles both from the teacher and students so that the learning outcomes of triple jumping were not maximal, namely there were still some students who did not understand basic techniques; The prefix (square), resting technique, tiptoe technique, stepping technique, and jumping technique (landing) can be understood that the implementation of these techniques is needed or required a good understanding, attitude and skills as well as concentration. However, one thing that needs to be maintained and appreciated by students is the attitude of discipline, cooperation, responsibility, motivation, sincerity, and student desire very well so that enthusiasm in learning is very high. This is evident from the active role of students when learning takes place, repeatedly students ask the teacher to do the movements that have been taught. In the process of learning the very good attitude possessed by students is the attitude of courage, responsibility, sincerity, and students' craving is very high so that learning activities can take place well.

In cycle II the triple jump learning process through used tires and cardboard aids to students of class XII IPS 5, students appear to be better and satisfying enough, because all students are seen participating in activities and attitudes following the learning process. The action given in the second cycle is to fix all the weaknesses or obstacles that were made by the teacher and students in the first cycle, among others; students who have difficulty doing tiered techniques and steps that are sometimes in the wrong order, teachers and collaborators quickly guide and help students. Then the research team together with collaborators gave special attention and guided specifically to students who lacked understanding (often confused) in carrying out resting board techniques and jumping (landing) techniques in sandboxes.

The results of observations and notes of the researchers together with collaborators in this second cycle assessed that the triple jumping technique in class XII IPS 5 Bone, Bone Regency was getting better, this can be proven when evaluating learning (cycle test) students have experienced a good increase by seeing the average class before the action is given that is 73.03 increased in the first cycle of 76.46, and in the second cycle increased again to 79.5 . However, the triple jump learning outcomes according to the success indicators previously determined there is still one student whose jump ability and skill have not yet been able to reach the completeness criteria.

From the explanation of each cycle's activities, cycle I and II show that the observations of students in jumping learning are always good, besides encouraging students to take part in learning activities provided by the teacher by using used tires and cardboard tools to make students feel motivated to be able to do tiptoe, step and jump techniques. Thus the second 
cycle has reached the target and even exceeded the desired target of researchers, namely $80 \%$ of the total students have reached the KKM value.

In accordance with the opinion of Devi Ari Mariani (2008), which states that playing for a child is not just filling time, but the media for children to learn . While Utami Munandar (Andang Ismail, 2009: 1), that playing as an activity that helps children achieve complete development, both physical, intellectual, social, moral and emotional. This study provides a clear picture that the success of the learning process depends on several factors.

These factors come from the teacher and students as well as the learning tools used. Factors on the part of the teacher are the ability of the teacher to develop the material, the ability of the teacher to deliver the material, the ability of the teacher to manage the class, the approach used by the teacher in the learning process, as well as the techniques and teaching aids used by the teacher as a means to deliver the subject matter. While the factors of students are students' interest and motivation in participating in the learning process. An interesting learning aid can also help student motivation so that optimal learning outcomes will be obtained in this case especially the use of used tires and cardboard aids that are cheap and easy to procure are very effective results. These factors are mutually supportive of each other, so it must be maximally pursued so that all these factors can be owned by the teacher and students in the learning process that takes place in class and in the field. If the teacher has a good ability to deliver the material and manage the class and is supported by techniques and facilities and infrastructure that are appropriate / effective and adequate, the teacher will be able to deliver the material well. The material will be accepted by students if students also have a high interest and motivation to be active in the learning process. Thus, teaching and learning activities can run smoothly, conducive, effective, and efficient.

This study also provides a clear description that through used tires and cardboard aids can improve student learning outcomes, so this research can be used as a consideration for teachers who want to choose alternatives in teaching PJOK especially triple jumping.

For teachers in Physical and sports Physical Education (PJOK) studies, the results of this study can be used as an alternative in carrying out the learning process of PJOK especially those related to increasing effective and interesting triple jump learning outcomes that make students more active and erase students' perceptions of learning PJOK which was initially boring became enjoyable learning. Especially for teachers who have more creative abilities in making learning approaches that are more varied. He or she can channel these abilities and utilize the facilities available in schools in an effort to improve performance as a professional and innovative educator.

PJOK learning which was initially boring for students, became fun learning for students. Provision of actions from cycles I and II provide a description that there are weaknesses that occur during the learning process. However, these deficiencies can be overcome in the implementation of actions in the next cycle (cycle II). From the implementation of the actions which are then reflected on the learning process, it can be described that there is an increase in the quality of PJOK learning both in the process and in increasing student learning outcomes in triple jumping.

\section{Conclusion}

From the results of data analysis and discussion previously stated, the conclusion can be concluded that through the use of used tires and cardboard tools, can improve learning outcomes triple jump in Class XII IPS 5 students of SMA Negeri 3 Bone, Bone Regency, this is evidenced by the increased process and completeness of the results student learning namely; 
In the action students 'learning completeness $46.87 \%$ increased in the first cycle of students' learning completeness $71.87 \%$ and in the second cycle increased students 'learning completeness reached $96.87 \%$, which means that students' learning completeness was in accordance with the target achievement in the specified research indicators.

\section{THANK-YOU NOTE}

Thanks to the Bone 3 High School for helping to give permission to conduct this research. Thank you also to journal organizers who have provided input and suggestions for improving the writing and helping with the publication of this article.

\section{References}

[1] Suherman, Dasar-Dasar Pendidikan Jasmani. Jakarta: Direktorat Pendidikan Dasar dan Menengah Departemen Pendidikan Nasional, 2001.

[2] Saputra, Y.M, Dasar-Dasar Keterampilan Atletik: Pendekatan secara Profesional. Jakarta: PT. Elex Media Komputindo Kelompok Gramedia, 2001.

[3] Arikunto dan Suharsimi, Penelitian Tindakan Kelas. Jakarta: Bumi Aksara, 2014.

[4] Parjono, et al, Belajar Berlatih Gerak-Gerak Dasar Atletik Dalam Bermain. Jakarta: PT. Raja Grafindo Persada., 2007.

[5] Gunawan, Metode Penelitian kualitatif Teori\& Praktik. Jakarta: Bumi Aksara, 2014.

[6] Sugiyanto, Pendidikan Jasmani Olahraga dan Kesehatan untuk SMA. Jakarta: Perbukuan Kementerian Pendidikan Nasional, 2010.

[7] Depdiknas, PanduanPengembangan Silabus Mata Pelajaran Pendidikan Jasmani BSNP. Jakarta: Depatermen Pendidikan Nasional, 2006

[8] Djumidar. Dasar-dasar Atletik:1-12,. PPDO2101/4. Cet.3. Jakarta: Pusat Penerbitan Universitas Terbuka Depdiknas, 2001.

[9] Gerry A. C. Belajar dan Berlatih Atletik. Bandung: Pioner Jaya, 1997

[10] Gina, H.,et al. Belajar Keterampilan Motorik, Pengantar Teori dan Metode. Jakarta: Departemen P\&K Dirjen Dikti Proyek Pengembangan Lembaga Pendidikan dan Tenaga Kependidikan, 1998.

[11] Joyoatmojo, Soetarno, Modifikasi Alat Pembelajaran. Jakarta Kencana Prenada Media Grup, 2003.

[12] Kosasih, Engkos, Olahraga Teknik dan Program Latihan.Jakatra: Akademika Pressindo, 1983.

[13] Masnun, Dadang. Pendidikan Jasmani dan Kesehatan. Jakarta: Depdikbud. Dirjendikti Proyek Pembinaan Tenaga Kependidikan, 1999

[14] Poerwodarminto, Kamus Besar Bahasa Indonesia. Jakarta: Balai Pustaka, 2002

[15] Sanjaya,Wina, Kemampuan Dasar Guru Dalam Proses BelajarMengajar. Bandung PT. Remaja Rosda, 2006

[16] Subagyo, et al, Pendidikan Jasmani Teori dan Praktek. Jakarta: Erlangga, 2005.

[17] Sudjana, Nana, Dasar-Dasar Proses Belajar Mengajar. Bandung: Sinar Baru Algensindo,2005

[18] Supartono, Sarana dan Prasarana Olah raga. Departemen Pendidikan Dasar dan Menengah Bagian Proyek Penataran Guru SLTA Setara DIII, 1999/2000.

[19] Yoyo,Bahagia, Modifikasi Pembelajaran Pendidikan Jasmani. Jakarta:Fasilitas Perlengkapan Penjas Fakultas Pendidikan Olahraga dan Kesehatan Jurusan Pendidikan Olahraga Universitas Negeri Jakarta, 2010. 
